\title{
The Making of Local Public Sphere: \\ Case Studies in Kebumen Regency and Batu City in Central and East Java
}

\author{
I GUSTI NGURAH PUTRA \\ Universitas Gadjah Mada, Indonesia
}

\begin{abstract}
Studies on democracy in Indonesia focus mainly on aspects related to the basic characteristics of democracy such as the existence of elite circulation through elections that allow everyone to hold power through a democratic process, the existence of political parties as instruments in political recruitment and aspects of procedural democracy and other institutional aspects. This study, in line with the spirit of democratisation in Indonesia, coupled with regional autonomy, focused on the formation of a public sphere in the transition to democracy at the local level by using the Kebumen Regency and Batu City as the main cases. The selection of these two regions was based on the consideration of the awareness of local elites in both regions to create the public sphere by establishing TV broadcasting stations that theoretically could reach the majority of citizens and involve citizens to discuss a wide range of common issues they face. The paper was based on a research conducted in the two regions using a case study approach. The research employed two main methods, namely in-depth interviews with informants involved in the establishment and management of the media (Ratih TV Kebumen and Agropolitan TV in Batu City) and used documents on the establishment and management of the two TV stations.
\end{abstract}

Keywords: Public sphere, democracy, public broadcasting, Ratih TV, Agropolitan TV.

\section{INTRODUCTION}

In recent studies about democracy, the existence of public sphere is often used as one of the important indicators to look at the democratic substance of a country or political entity (Tilly, 2007; Koopmans \& Statham, 2010; Verstraeten, 2000; Clemens, 2010; Guidry \& Sawyer, 2003; McLaverty, 1998; Hasfi \& Rahardjo, 2019). It is positioned as an important element considering that public sphere provides sphere and at the same time a climate or atmosphere to discuss various common issues in a rational and free manner without being controlled either by the market, the state or even the existing socio-cultural forces so that public opinion can be formed (Habermas, 1989, see also Chakravarty, 2017). In various developed democracies, the existence of the public sphere has long been an inseparable part of the democratic process. In new democracies, attention to the existence of the public sphere is beginning to receive attention (See for example Buehler, 2010; Juliana, 2011; Aspinall \& Berenschot, 2019, Rianto, 2020). The problems that arise are usually related to the existence of intensive interventions on the public sphere both by the state and commercial interests.

Some countries that carry out political reforms to become democratic countries generally make a long struggle in building the public sphere as an important part of the democratization process. Indonesia is not an exception. Indonesia's struggle in building the public sphere at the national level took place long before the country launched political reforms, mainly because during the New Order government, the existence of the public sphere was always in state intervention and then followed by the market intervention (Dhakidae, 1991). The success in forming a more democratic public sphere as part of 
democratisation is determined by various factors, especially those that are prominent in civil society.

Every polity needs a public sphere with which the citizens can debate what they will do together as citizens of that polity. For example, the formation of a European Society consisting of 27 countries requires the establishment of a public sphere that allows citizens from the twenty-seven member states to first know the common issues they face and also debate how to find solutions to these issues. They are struggling to build a public sphere at the European level which allows them to discuss issues at the level of European society. A study by Koopmans and Statham (2010) on the formation of the public sphere at the European level provides relevant data on the inevitable existence of the public sphere in each democratic political entity.

The struggle in building the public sphere has become increasingly important in countries that are making the transition to democracy from what was previously an authoritarian state. The experience of countries in Eastern Europe after the collapse of the Soviet Union's dominance and the formation of new countries in Eastern Europe, besides being marked by the formation of more democratic governments, there was also a long struggle in building the public sphere as an important part of the transition phase they went through. This struggle did not fully succeed in building the public sphere they hoped for due to various factors such as the still weak civil society groups, piracy by the elites, and so on. Some countries have succeeded in developing relatively democratic public spheres after a long journey (see for example Lubinski et al., 2014; Radovic \& Luther, 2012; Bekerman, 2014), while some other countries' struggle in building the public sphere is straddled by past political elites so that the built public sphere is dominated by political elites (Milton, 2001). Mass political actors then dominated the formation of the public sphere for their interests, not as an arena for the common good (Milton, 2001; Metykova, 2007; Mungiu-Pippidi, 2000).

In the context of democratisation and at the same time decentralisation that accompanied Indonesia, demands for the existence of the public sphere are inevitable. The formation of regional autonomy by giving broader authority to the regions to determine various issues also requires the formation of the public sphere that allows citizens in each autonomous region to know the various issues they face and debate so that the participation of citizens in politics can build a substantive democracy.

Until now, studies on how regimes at the local level have struggled in building public sphere as part of the process of political democratization at the local level are still very limited. One study of local public sphere was carried out by Buehler (2010) who saw the marginalisation of local public sphere. Many studies of political democratisation at the local level still focus on the existence of local media as an important part of local politics (Hill, 2007) or about contestation in seizing power by elites (Aspinall \& Fealy, 2003; Haryanto, 2013).

This study is important in view of the following: Firstly, this study broadens the focus of studies on democracy at the local level which is not only limited to procedural and substantive democracy, but also examines deliberative or contentious democracy as proposed by Tilly (2007). Secondly, this study is expected to describe the struggles of local regimes in building the public sphere that allows citizens to engage in politics. Thirdly, this study is expected to be a breakthrough in studies of democracy in new democracies on the public sphere as an important indicator of democracy. 


\section{LITERATURE REVIEW}

The concept of the public sphere to be used in this study refers to Habermas's thinking about a public sphere that began to expand its use after his Structural de Offentlichkeit work, translated in 1989 into English into Structural Transformation of the Public Sphere. In the preface; the translated book written by McCarthy $(1989, \mathrm{p}$. xi) states that this book is a study of historical sociology about the emergence, change, and disintegration of the bourgeois public sphere. The public sphere is conceived of as a sphere where people can express their opinions without constraints with the guarantee of freedom of association, association, and freedom of speech, and express opinions on various common problems. (Held, 1980, p. 260). Members of the community can openly discuss matters relating to achieving consensual solutions based on debate rather than relying on traditional dogmas or authority such as the privileges of kings. The standard of critical thought forms the basis of much debate.

McKee formulated public sphere as "A domain of our social life where such a thing can be formed [where] citizens. . . deal with matters of general interest without being subject to coercion. . . [to] express and publicize their views" $(2005$, p. 4). Thus, the main character of a public sphere is equality between parties; equality of interests/attention to shared problems without pressure or coercion, and participation in expressing views.

The importance of deliberative democracy as a new form of democracy to complement democracy that focuses on election/ voting begins to develop in line with the emergence of oligarchic political elites which causes democracy to only serve groups that succeed in entering the arena of power. Democratic elections do not create public policies that can fulfil the wishes of a large number of citizens if not all citizens. Democratic elections do not produce policies that reflect the public interest. To compensate for a democratic model that focuses on 'voting', some theorists offer a democratic model that pays more attention to increasing the role of 'public reasoning' in political decision making. The argument used to support this is the existence of three models of collective decision making, namely through voting, bargaining, and deliberation (Gripsrud et al., 2010, p. xix).

Deliberative decision making in democracy places democracy as a forum that sees participants entering the forum in a position that is not yet fully certain so that it is still possible to change choices. They are seen in debates and discussions that might change their choices or preferences or at least strengthen the preferences they already have through deliberation. With this consideration, the existence of the public sphere for deliberation becomes very important (Gripsrud et al., 2010, p. xix).

According to Tilly (1995), the public sphere is interesting as one indicator of the development of a new form of 'political contention' which ultimately becomes an inseparable part of the democratic process. Tiwari $(2006$, p. 639) holds that the public sphere is not only useful for the maturity of public opinion, but also acts as an agent that allows and provides democracy of essence and substance. Democratisation proceeded with the increasing number of people involved in discussions in the public sphere. Citizens become active public seeking information as a basic material that can be used to participate in debates in public spheres (Clemens, 2010, p. 375).

\section{METHODOLOGY}

In the transition to democracy at the local level, the struggle for the formation of the public sphere occurs in many places, with the efforts of local leaders to provide media that serve citizens and make it a public sphere. From many regions that are struggling in the formation 
of the public sphere, Kebumen Regency and Batu City are the two regions that did it relatively early on Java. These two regions have different characters in several ways. First, Kebumen Regency is a relatively large autonomous region in the Central Java region with more than 30 subdistricts and a population of more than one million inhabitants, while Batu City is an autonomous region with a relatively small region with three subdistricts and a population of around 200 thousand people. Second, Kebumen Regency is an autonomous region that has been established for a long time, and has a long history as an autonomous region, while Batu City is a new autonomous region to develop the Batu Administrative City as part of the development of Malang Regency. In addition to the differences, the two regions have similarities in their struggle to build the public sphere by establishing local public broadcasting institutions in the form of television broadcasts namely Ratih TV in Kebumen and Batu City Agropolitan TV (ATV).

This study used a comparative case study looking at the struggle of the regimes in the two regions in building public spheres that expand democratic spheres. Data collection was carried out through in-depth interviews with various parties, especially those who were involved from the beginning and in the development of these two local public broadcastings including their managers, officials involved in the formulation of local public broadcasting policies, community members especially those included in the category as civil society groups. Triangulation was carried out to ensure the validity of the data by cross-checking with various sources and using existing documents to support the interview data. Data analysis was conducted using pattern matching, namely, matching existing data with theoretical prepositions that had already been established.

\section{RESULTS AND DISCUSSION}

\section{Significance and Condition of the Media as the Public Spheres}

Procedural democracy in the form of a process of changing political elites through democratic elections (see for example Gaffar, 1994, pp. xxvii-xxx) is realised at the local level. However, something is missing in the process, namely, the absence of a public sphere that allows all citizens in the two regions studied to have access to increasing citizens' knowledge about common problems and also those who fight in the struggle for power. A space that allows citizens, at a further level, to be able to discuss a variety of shared problems to produce a consensus that can be used as reference material in making solutions to these problems both politically through public policy and existing social life mechanisms. Public policy taken by the power holders is not solely based on the limited preferences they have, but by considering various discussions conducted by citizens in the public sphere. The existence of the media as a public sphere becomes a necessity. As a public sphere, the media can also control the holders of power so that the rulers can make policies following the public interest (see Aspinal \& Berenchot, 2019).

Media as a form of the public sphere is already available in many local polities. According to Aspinall and Berenchot (2019), the availability of a public sphere is one of the differences between the government that runs the reform agenda and the government that continues what happened during the New Order. There are several important issues related to the function of media as the public sphere. First, as a public sphere, the media tend not to be spread widely to all levels of the community, thus creating a tendency for information gaps between those who are rich in information due to large media access and those who are poorly informed because they do not have access to public communication. Second, the existing media are generally still managed through a market approach so that its main 
function is nothing more than an industry whose ultimate goal is profit-making for its owners. In many places, the mass media is not fully managed with a pure market approach, but through a pseudo market in the form of media, it is financed by business people who also plunge into politics to avoid the critical coverage.

The condition of the media as a public sphere in Kebumen can be described as follows. Print media has a circulation of no more than 10,000 copies throughout Kebumen (interview with K. Wardopo, August 20, 2015). The amount is not comparable with about 300.000 existing households in Kebumen. The existence of digital media is also not yet fully encouraging given the limited technical infrastructure of telecommunications for digital media both in terms of producers, distribution, and consumption. Teledensity data is not very encouraging. The number of fixed telephone owners in Kebumen is relatively small and they are mostly concentrated in urban areas. Cellular phone services are also more directed towards serving consumers in urban areas. In 2014, the number of home phone owners in Kebumen was 13,978 (Kebumen in Figures, 2014). For approximately five years, the number of home phone owners has not changed significantly. In 2010, the number of home phone owners was 9,474. The majority of home phone owners reside in Kebumen City $(4,754)$, followed by Gombong $(2,230)$ and Kutowinangun $(1,512)$. The number of internet customers is still small, only around 5,500. Compared to the number of families which reaches around 300,000 , the number of households that can access the telephone and Internet is still very small, not up to $10 \%$ (Kebumen in Numbers, 2014).

In such a media situation, broadcast media is the most appropriate choice to be positioned as a public sphere. This is because, first, the general public already has a television set and radio. Besides, broadcast media can be consumed by those with a low level of education. Referring to the 2011 Indonesian ICT Indicator Data published by the Ministry of Communication and Information, it can be estimated that around $90 \%$ of households in Kebumen have access to television. This media is the most extensive so that both media have a relatively stronger influence on the knowledge of citizens, including their knowledge of the dynamics of local politics in the Kebumen region. Based on the results of a survey conducted by the Kebumen District Public Relations Section within the framework of meeting the demands for information on the principles of Good Governance by the Kebumen District Government it was found that around $90 \%$ of Kebumen residents watched television broadcasts. (Interview with Rustriningsih, 1 August 2018; and Sukamto, 5 December 2018).

As a new autonomous city which is the development of Batu District, Malang Regency since the beginning of the reformation period, Batu City previously relied on mass media centered in the Malang city area as the public sphere. Both print and electronic media were operated from Malang so that Batu City at the beginning of its existence as a new autonomous region did not have media as a special public sphere that could be used as a space to share government activities or public knowledge. Nevertheless, Batu City, which is located in the highlands with several mountains and hills has been used as a base for television broadcast transmitters in Greater Malang. Oro-oro Ombo is known as an area to place a variety of television transmitters for Greater Malang. Technically, the residents of Batu City have very good access to electronic media broadcasts both television and radio. The problem is that television stations that place their transmitters in Oro-Oro Ombo are not directed to Batu City area. 
Batu City, which has small territory with a population of around 200 thousand, lacks adequate fund to support the print media industry economically. No print media company is based in Batu City to serve as a media of information for Batu City residents, specifically to publish information about various events and express opinions. Only Radar Batu, which is the subsidiary of the Surabaya-based giant media conglomerate Jawa Pos, is found in Batu City. However, since Batu City is well known as an important if not most important tourist destination in East Java, events or opinions related to the city have received quite good coverage both by local media based in Malang City and national media based in Jakarta. Some media companies place their journalists in Batu City or assign their journalists based in Malang to cover the events or opinions in Batu City. Such situation and condition of the media cannot certainly help the democratisation of society.

\section{The Role of Actors in Making Public Sphere}

The limitations of the public sphere are recognized by the actors in each region, either Kebumen Regency or Batu City. For Rustriningsih, as the Kebumen Regent who was elected through a fierce election in the parliament, the limitations of the public sphere made it difficult to increase the community's participation in advancing Kebumen Regency. Besides that, it also causes difficulties for her programs as a regent to receive full support from residents because they do not know these programs. At that time there was also a growing demand for the application of the good governance principles developed by the Partnership for Reform Program. The good governance principles deal with, among others, components of participation, transparency, and accountability. In participation, government institutions must involve various stakeholders. The principle of transparency emphasizes the openness of government institutions to stakeholders.

To respond to all this, Rustriningsih then took some strategic steps by, among others, developing activities called five media plus, namely Ratih TV, Radio in FM, Press Center, Website, Direct Mail and Library and Video (Interview with R. F. Sunaryo, 2015) to increase public participation and government transparency. The communication media developed were not only a means of government communication but also a tool to increase community participation in helping the government (Interview with Rustriningsih, 1 August 2018). In other words, it develops the public sphere that allows citizens to not only obtain various information about government activities, policies, and programs and participate through open dialogue with the government, but also to discuss various issues or problems developing in Kebumen Regency.

To make it happen, many challenges arise. The idea of establishing Ratih TV was not fully supported by politicians or parties, especially non-government supporting parties. Some parties saw that the establishment of Ratih TV would give a strong weapon to the Rustriningih government. In fact, the Nation Awakening Party (PKB) Faction also questioned the plan to set up Ratih TV during the deliberation on the draft regulation of Kebumen Regency concerning Local Public Broadcasting Institution (LPP). But with the argument that Ratih TV can basically be used not only by the government/executive, but also by the legislature, the challenges of this party slightly reduced. Especially after the operation, the presence of Ratih TV was slowly accepted and appreciated by the citizens, so that criticism from politicians diminished (Interviews with Sukamto, 5 December 2018 and Rustriningsih, 1 August 2018).

Since then, support for Ratih TV as the public sphere has continued through legal measures so that it has a strong legal basis in the form of Broadcasting Permit (IPP). After 
going through a long process, Ratih TV eventually secured an IPP from the Ministry of Communication and Information under Decree No. 1255/2013. The IPP has laid a strong foundation for the establishment of Ratih TV as a legally strong public sphere.

Slightly different from Kebumen, the first Mayor of Batu, Iman Kabul was a bureaucrat. For the government bureaucracy, the absence of information media that can be accessed by the local public becomes a challenge when they need to disseminate information on government activities and programs to citizens. Local elites, especially those from the state sector, are trying to develop communication media to disseminate government programs, which will in turn also serve as a means of opening the public spheres for Batu City residents.

The Batu City Government under the leadership of Mayor Imam Kabul assigned Syamsul Huda, a Batu City government employee, to develop a "Tourism Information Radio" broadcasting project. This project is based on the idea that to overcome constraints in the dissemination of information to rural areas and constraints in the development of human resources, the city government can rely on radio (Yazak, 2012, p. 43). In its further development, this project eventually turned into a television development project which was later called Agropolitan TV (ATV). The development of this broadcast media signifies the creation of space that allows the citizens of Batu City in the first stage to know various common problems that arise in the Batu City area. In the next stage, through this broadcasting media, Batu City residents can discuss openly, rationally and freely various common problems that develop in Batu City in line with the growth of Batu City as an important tourist city not only in East Java, but also in Indonesia.

In its development, ATV faced a number of obstacles to be able to become a local public broadcasting institution in order to function as a public sphere. The first thing was about its legal form that could be used. ATV was supposed to come in the form of ordinary local TV (commercial), but after taking into account the law and taking care of permits the city government chose non-commercial local public broadcasting for ATV. In addition, there are obvious obstacles related to human resources. The biggest challenges and obstacles come from within the government and also the parliament that must allocate a budget for ATV. Batu City government officials questioned the urgency of local television (Yazak, 2012, p. 44). The high investment and operational costs for broadcasting spark pros and cons among legislators.

From the beginning there have been demands for the operation of ATV which is able to contribute to locally-generated income (PAD) to cover the sizable amount of budget funds needed for its investment and operational costs. Both officials/executives and legislators have highlighted the importance of ATV to contribute to locally-generated income (PAD). After passing through various pros and cons, ATV was finally agreed to be established.

Legal support for the establishment of ATV continued until it finally obtained an inprinciple permit and IPP. The issuance of the Decree of the Minister of Communication and Informatics of the Republic of Indonesia No. 1260/2016 regarding the In-Principle Licensing for the Operation of Local Public Broadcasting Television Agroplolitan Television Service, has laid a legal basis for the establishment of ATV. This in-principle license is further strengthened by the issuance of an IPP (broadcasting permit) based on the Decree of the Minister of Communication and Information No. 1374 of 2017 concerning the Agropolitan TV Local LPP Broadcasting Permit dated July 11, 2017.

Dominance of Voices in the Public Sphere 
As public sphere, both Ratih TV and ATV have since the beginning been directed to be a sphere that gives more space to the interests of the government. News programs and dialogue programs that enable the emergence of citizens' voices are dominated by news of government activities and dialogue that gives more room to government representatives. However, it is also undeniable that both Ratih TV and ATV have a strong potential to make room for the voices of community representatives. Both in certain moments and situations they provide a place for the interests of community groups, although relatively limited. It is important to note that with the presence of Ratih TV and ATV, the governments of both regions have opened the local public sphere because: first, the presence of Ratih TV and ATV opens space for transparency of the ongoing political process. Unlike in the past when there were limitations on what would be 'publicised' and what would remain out of reach of the public, with the presence of Ratih TV and ATV, everything could become public and become public property when Ratih TV and ATV raised it both as news material and dialogue material. Secondly, when events or ideas have become information or have been debated and disseminated through Ratih TV and ATV, it can be expected to be a concern and also a public discussion.

Rustriningsih, who initiated Ratih TV, from the beginning wanted to develop Ratih TV into media that allows the implementation of interactive communication, especially between government and citizens (Sukamto, 5 December 2018). Ratih TV Kebumen is directed to be broadcasters that provide opportunities for citizens to participate, in the form of reporting various problems arising in the community and proposals for solutions offered, regardless of its status as state media at that time. The most concrete manifestation is through a program that helped raise the name of Rustriningsih and also Kebumen Regency, "Good Morning Regent" (Selamat Pagi Bupati) around Indonesia.

The broadcast program, "Good Morning Regent" provides space for citizens to lodge complaints, criticisms, input on various issues faced by the people of Kebumen. For the community members who have always listened to government explanations and information, the presence of Ratih TV has turned everything around. In addition to delivering various programs that the regent has made, the community members were also free to express their aspirations through the "Good Morning Regent" program.

Through this program, there are many things that can be achieved, such as (1) a form of discipline and at the same time the responsibility of the subordinates of the regent for their performance; (2) Community members have the opportunity to directly express their problems openly and also feel valued as human beings; (3) After all, the community members get to know their regent with their programs; (4) Citizens can also find out various problems raised by Kebumen residents so that eventually they increase awareness about the problems in Kebumen.

Some of the residents' complaints were immediately responded to by the regent. If the problem is technical, the regent sometimes asks the SKPD Head to participate in explaining it. Through this broadcast, the community gets space to directly dialogue with the regent. However, there is no data on how many watches this program.

This program was eventually replaced by Rustriningsih's replacement with "Good Morning Kebumen". This change occurs not only in the name of the program, but also in terms of appearance. The regent no longer shows up every day to greet Kebumen residents through Ratih TV. He only appears once a week and the rest is filled by the head of the office of the regent's subordinate. Due to a change in working hours from six working days to five working 
days a week, Saturday's broadcast was cancelled and replaced with another program, namely Morning Inspiration.

An accident that creates a program carries more or less the true character of public TV. Unlike the Good Morning Regent or Good Morning Kebumen, the 'Insprirasi Pagi' (Morning Inspiration) program was managed by an NGO leader who successfully invited community leaders to discuss various current issues being discussed by the community (Interview with Kholid Anwar, 26 August 2015 and Murtajib, August 25, 2015).

The Morning Inspiration Program, which is a substitute for the Good Morning Regent Program on Saturday, is expected to provide space for community leaders to discuss community issues that become public discussion. Kholid Anwar, who is a member of the Ratih TV Supervisory Board, asked Murtajib to fill the program by hosting a broadcast once or twice. However, because it succeeded in bringing this program into one of the leading programs, Murtajib's assignment as a host lasted for about 6 to 7 months. The main host or moderator is Dwi Purwantoro or better known in the Kebumen broadcasting world as Mas Pandu. Murtajib usually takes responsibility for formulating themes to be discussed and determining the sources for each theme. However, he also frequently acts as a resource or host. Resource persons who are usually invited are non-governmental people, especially from NGOs or community leaders.

The involvement of community leaders and NGO leaders received a favorable response from the community. The previous program, which featured more officials' faces, made public figures less likely to get a place. Positive responses came from various NGO leaders and leaders of various communities because they were allowed to appear as resource persons. For community leaders and NGOs, they can appear on Ratih TV as if they get recognition or the legitimacy of their figures. They need space to convey their ideas and thoughts. Indeed, today people can talk or express their thoughts through various social media such as Facebook. However, appearing on Ratih TV is different from speaking on social media. On social media, anyone can appear, while on TV only a select number of people can appear. The Morning Inspiration Program hosted by Murtajib only lasted about seven months.

Kholid Anwar, who is a member of the Board of Trustees, represents community leaders and media practitioners realised that, while he was a member of the Board of Trustees, the content of Ratih TV was dominated by government interests and voices. Therefore, although he was not able to formulate a coverage policy that had to be carried out by Ratih TV, in terms of the program, he tried to offer programs that featured more community activities. He could do that because Kholid Anwar as the Supervisory Board has the right to make the program as compensation for the lack of salary he received as a member of the Board of Trustees. Through involvement in this program, he is entitled to an honorarium (Interview, 3 May 2018). According to him, it is very reasonable because Ratih TV still has its main office in the Public Relations and Protocol Division. Practically all regents' activities must be covered by Ratih TV because one of the tasks of the public relations department is to communicate and promote the activities of regional heads.

Batu City ATV does not have the icon as it was once owned by Ratih TV which broadcasts live the dialogues of Rustriningsih with Kebumen residents every day. ATV, like Ratih TV, creates an important public sphere for residents of Batu City because, among other things, it provides local information both related to government policies, programs, and activities. It also broadcasts various ideas, activities, and problems faced by residents of the City of Batu. ATV becomes an important media that makes government activities always 
known by citizens. This is important in the context of a local democracy because local people can evaluate the government. Moreover, ATV also provides a discussion forum that allows citizens to discuss various important issues at the local level/in the City of Batu.

When its status is government media, ATV's main obligation is to broadcast the Batu City government programs in developing tourism. However, in its reporting program, ATV fully covers not only government activities, but also various social events that have extraordinary news value, such as the arrest of the terrorist kingpin, Dr. Azahari who happened to be paralysed in Batu City (Hariadi, interview 6 September 2018).

The change in status from state media to public broadcasting institution prompted ATVs to change their orientation from reporting that focuses on the government to report that focuses on public affairs and citizen's activities. Besides, the pressure to add additional revenue to Batu City yearly income encourages its management to create events that serve the public interest to attract advertising. (Interview with Hariadi, 6 September 2018).

In contrast to Ratih TV, which on its journey has never been managed commercially, ATV has cooperated with Kompas TV, so it tended to serve commercial interests. The purpose of this cooperation, in addition to alleviating the burden of the government, is also to provide a budget and contribute to the locally-generated income of Batu City. This cooperation caused ATV to reduce programs that involved local people by presenting national programs (http://pemilu.tempo.co/read/news/2011/09/15/180356438/Program-Change-

Commission-Broadcasting-Persoalkan-Agropolitan-TV). A study conducted by Yazak (2012) also showed that the failure of ATV became a public sphere when ATV cooperated with Kompas TV.

The cessation of cooperation with Kompas TV caused the ATV to broadcast local programs again. However, broadcast programs in the form of interactive dialogues involving local sources in Batu City such as I Love Malang Raya, Dialog Siang or Dialog Pusaka, some of the fillers were chosen for promotional purposes or invited speakers from organizations that sponsor the event. Observations of events that give space to the public in a month (April 2018) indicate that the interactive dialogue program has not fully provided a large space for community groups without any ties to sponsor. This could be a way to anticipate budget constraints and also the necessity to contribute to the Batu City annual income.

\section{CONCLUSION}

Even though the initial idea of establishing Ratih TV in Kebumen and ATV in Batu City was not driven by the importance of these two media as a public sphere, the presence of this media would eventually become a public sphere considering that various news programs or journalism in all its forms more or less made something which was initially known only by a few people, after being covered and broadcast by both of these media will become public property. Furthermore, what is broadcast by these two media can open a dialogue, discussion among citizens. Specifically for Ratih TV, the program of the Good Morning Bupati gives space to residents to convey things that are only known by a select number of people. When in their development, these two TVs eventually become local public broadcasting and because of the regulation, their potential as a public sphere could be even greater and stronger. The problem is that the figures who take the helm of these two cities do not necessarily consider the existence of the media as a public sphere.

An attempt to place figures close to the holders of power in the management structure of the two media indicates that there is an effort to control this public sphere in the interests of the authorities. The impact can be seen from, among others, the choices of programs being 
developed and also the issues being discussed. However, it remains open that media workers emerge with a strong awareness of journalists so that they are more autonomous in determining what activities need to be covered and reported and what activities do not need to be covered. The same thing also happened to dialogue programs aired in both media. The two TVs have the potential to function as the public spheres that provide a place for a variety of views and free discussion.

The direction of the development of these two media, among others, is very much determined by the political elite in both the executive and legislative branches. Local civil society leaders can play an important role in making this media a public sphere if they want to be involved to fill interactive dialogue programs by developing their capacity through increasing communicative competence.

\section{ACKNOWLEDGEMENT}

This research is partly funded by The Center for South East Asia and Social Science, Universitas Gadjah Mada, Yogyakarta.

\section{BIODATA}

I Gusti Ngurah Putra is an associate professor at Department of Communication Science, Universitas Gadjah Mada, Yogyakarta, Indonesia. Email: gnputra@ugm.ac.id 


\section{REFERENCES}

Aspinall, E., \& Fealy, G. (2003). Local power and politics in Indonesia: Decentralization and democratization. Singapore: ISEAS.

Aspinall, E., \& Berenschot, W. (2019). Democracy for sale: Elections, clientelism and state in Indonesia. London: Cornell University Press.

Bekerman, M. (2014). From the field: The failure of a success story: Reforming Georgia's public service broadcaster. Global Media Journal German Edition, 4(2), 1-23.

Buehler, M. (2010). Decentralization and local democracy in Indonesia: The marginalisation of the public sphere. In E. Aspinall \& M. Meitzner (Eds.), Problems of democratization in Indonesia: Elections, institutions and society. Singapore: ISEAS.

Chakravarty, D. (2017). Reading popular music festivals through the lens of public sphere. Jurnal Komunikasi: Malaysian Journal of Communication, 33(1), 32-42.

Clemens, E. S. (2010). Democratization and discourse: The public sphere and comparative political research. Social Science History, 34(3), 373-381.

Dhakidae, D. (1991). The state, the rise of capital and the fall of political journalism (Unpublished dissertation. Ithaca, Cornel University).

Gaffar, A. (1994). Demokrasi dan prospeknya di Indonesia orde baru. In E. P. Taher (Ed.), Demokratisasi politik, budaya dan ekonomi: Pengalaman Indonesia massa orde baru. Jakarta: Yayasan Paramadina.

Gripsrud, J., Moe, H., Molander, A., \& Murdock, G. (Eds.). (2010). The idea of public sphere: $A$ reader. Plymouth: Lexington Books.

Guidry, J. A., \& Sawyer, M. Q. (2003). Contentious pluralism: The public sphere and democracy. Perspective on Politics, 1(2), 273-289.

Habermas, J. (1989). The structural transformation of public sphere: An inquiry into a category of bourgeois public sphere. Cambridge, Mass: the MIT Press.

Haryanto. (2013). Politik kain timur: Studi pemanfaatan tradisi sebagai instrumen mobilisasi dukungan untuk meraih kekuasaan dalam pilkada di kabupaten sorong selatan, tahun 2010 (Unpublished dissertation, Universitas Gadjah Mada, Yogyakarta).

Hasfi, N., \& Rahardjo, T. (2019). The disable people virtual communities in social media from the perspective of public sphere theory. Jurnal Komunikasi Ikatan Sarjana Komunikasi Indonesia, 4(2), 65-76.

Held, D. (1980). Introduction to critical theory: Hokhiemeir to Habermas. London: Hutchinson.

Hill, D. (2006). Manoeuvres in Manado: Media and politics in regional Indonesia. South East Asia Reserach, 15(1), 5-28.

Juliana Abdul Wahab. (2011). Television talkshow and the public sphere. Jurnal Komunikasi: Malaysian Journal of Communication, 27(2), 29-45.

Koopmans, R., \& Statham, P. (2010) The making of a european public sphere: Media discourse and political contention. New York: Cambridge University Press.

Lubinski, J., Albretch, E., Berner, P., Schneider, L., Wakili, M., \& Wilson, J. (2014). From the field: Windows of opportunity - The transformation of state media to public service media in Kyrgyzstan, Mongolia, Moldova and Serbia. Global Media Journal German Edition, 4(2).

McCarthy, T. (1989). Introduction. In J. Habermas (Ed.), The structural transformation of public sphere: An inquiry into a category of bourgeois public sphere. Cambridge, Mass: The MIT Press.

McKee, A. (2005). The public sphere: An introduction. Cambridge: Cambridge University.

McLaverty, P. (1998). The public sphere and local democracy. Democratization, 5(3), 224-239. 
Metykova, M. (2007). Establishing public service broadcasting in the Slovak republic (1993 to 2004): From state control to the single European market. Trends in Communication, 12(4), 223-232.

Milton, A. K. (2001). Bound but not gagged: Media reform in democratic transitions. Comparative Political Studies, 34(5), 493-526.

Mungiu-Pippidi, A. (2000). State into public: The failed reform of state TV in East Central Europe (Working Paper Series, The Joan Shorenstein Center on the Press, Politics and Public Policy, Harvard University).

Radovic, I., \& Luther, C. A. (2012). From State controlled to public service broadcasting: Signs of change in Serbia's RTS television newscasts 1989-2009. Journal of Broadcasting and New Media, 56(2), 245-260. https://doi.org/10.1080/08838151.2012.678517

Regional Planning Board of Kebumen Regency in collaboration with Central Board of Statistics of Kebumen Regency. (2014). Kebumen in figures 2014. Kebumen: BPD Kebumen.

Rianto, P. (2020). The loss of public sphere: Outdoor advertising and commercialization of public spaces in Sleman, Yogyakarta, Indonesia. Jurnal Komunikasi: Malaysian Journal of Communication, 36(1), 509-522.

Tilly, C. (1995). Contentious politics in Great Britain, 1758-1834. Cambridge, MA: Harvard University.

Tilly, C. (2007). Democracy. Cambridge: Cambridge University Press.

Tiwari, R. (2006). Habermas's views on the significance of the public sphere in a democracy: Its possible relevance in understanding the public sphere in India. The Indian Journal of Political Science, 67(3), 639-650.

Verstraeten, H. (2000). Media, democracy and the public sphere: Towards a Reconceptualization of the Public Sphere. Communicatio: South African Journal for Communication Theory and Research, 26(1), 73-83.

Wardopo, K. (2015, August 20). Print media circulation throughout Kebumen [Interview].

Yazak, E. M. (2012). Kepentingan dibalik Perda no. 8 tahun 2009 tentang Lembaga Penyiaran Publik Lokal Agropolitan TV Kota Batu (Unpublished Thesis Postgraduate Program Communication Science, Universitas Gadjah Mada, Yogyakarta). 